\title{
Wood properties: future needs, measurement and modelling
}

\author{
Francis Colin $^{1,2}$ • Marie-Pierre Laborie ${ }^{3}$ Mathieu Fortin ${ }^{1,2}$
}

Received: 4 June 2015 / Accepted: 23 June 2015 / Published online: 21 July 2015

(C) INRA and Springer-Verlag France 2015

\section{Challenges regarding wood}

Wood products differ from other manufactured products by the fact that they originate from raw material developed in forest trees, according to complex biological processes, influenced by environmental conditions and changes. These conditions depend on silviculture, in turn influenced by economic, ecological, and social factors.

Forests are an important carbon sink. The subsequent sequestration of carbon in wood products is allowed by the consumption of durable products corresponding to traditional and innovative utilizations.

Within this context, one of the main challenges for the current forest-wood research is to bring together the knowledge on how wood properties are developed and can be controlled in forests and the performance required for traditional and emerging end-use wood products. The success as raw material and as manufactured and sometimes complex products requires an improved understanding of wood properties and the capacity of accurately measuring them, both in standing trees and not far to the service conditions, and assembling

Handling Editor: Erwin Dreyer

Francis Colin

colin@nancy.inra.fr

Marie-Pierre Laborie

marie-pierre.laborie@fobawi.uni-freiburg.de

Mathieu Fortin

mathieu.fortin@agroparistech.fr

1 AgroParisTech, UMR LERFOB 1092, F-54000 Nancy, France

2 INRA, UMR LERFOB 1029, F-54280 Champenoux, France

3 Forest Biomaterials, University of Freiburg, Werthmanstr.6, 79085 Freiburg, Germany the successive knowledge along the forest-wood chain in relevant models and simulation tools.

\section{The MeMoWood conference}

The International Conference on MEasurement methods and MOdelling approaches for predicting desirable future WOOD properties (MeMoWood) was the last meeting in date of the IUFRO Unit 5.01.04 "Wood Quality Modelling." MeMoWood took place in Nancy, France, from October 1 to 4, 2013 and was the 7th meeting of this unit since its launching in 1994. MeMoWood was also a satellite event of the European Forest Institute (EFI) 20th anniversary.

The event was co-organized by the Institut National de Recherche Agronomique (INRA), AgroParisTech and the Chair of Forest Biomaterials of the Faculty of Environment and Natural Resources at the University of Freiburg, Germany.

In line with the recommendations of the 6th meeting in Joensuu (Leban et al. 2009), the primary objective of the conference was to review the latest developments in the fields of measurement and modelling of macroscopic wood properties. In addition to this, the "study, modelling, and utilization of the microscopic and nanoscopic properties of wood" were also addressed during the conference, which was a novelty compared with previous IUFRO unit 5.01.04 conferences.

Eighty people from 20 different countries attended the meeting. A strong participation of researchers within the Nancy Freiburg Zurich Network (NFZ) nicely complemented this international event with a regional flavor. The discussions following 6 keynote speeches, 50 presentations, and 13 posters provided many opportunities to share knowledge on wood properties and methodological and modelling approaches during 3 days of sessions. A 1-day field trip to the Vosges Mountains (Alsace-Lorraine) also gave the attendees an 
overview of some issues related to the forest-wood chain in a regional French context. The abstracts and most presentations and posters are available on the website (https://colloque6. inra.fr/memowood/MeMoWood-presentations).

\section{New products from a diverse world-wide resource}

The emergence of the study of nanoscopic and microscopic properties was strongly justified by future needs for wood as reported by (Skog et al. 2013, 2015). This demand for new products will be met through a better knowledge of the wood material not only at the macroscale but also at the microscale and nanoscale (Salmén 2013, 2015), especially in standing trees (Fournier and Alméras 2013; Thibaut 2013).

Wood products come from a world-wide forest resource, and as such, they show a great diversity. An optimal exploitation of the resource requires an in-depth knowledge of the geographical distribution of the properties. The current distribution of the wood properties becomes more accessible thanks to remote sensing methods such as Airborne Lidar (Coops 2013), while the distribution of the future properties can be predicted with different degrees of accuracy by coupling models of tree growth and wood quality (Weiskittel 2013).

\section{Measurement methodologies}

Computed tomography (CT) stays at the front stage for wood imaging from the log scale to the micrometer scale. For example, acoustic (ultrasonic) tomography can be used alone to infer about the internal structure of standing living trees (Arciniegas et al. 2013, 2015) or in combination with electrical impedance tomography for the detection of ring shakes (Happe and Hapla 2013). At the macroscopic scale, X-raybased CT may be used to detect various wood quality traits, such as knot morphology, through manual (Duchateau et al. 2013) or automatic (Longuetaud et al. 2013) procedures, or thin epicormic traces (Morisset et al. 2013) and pith (Gazo et al. 2013). X-ray-based tomography is also valuable to map mechanical properties in round wood, as shown by good correlations between measured and simulated wood compression strength in small-sized broadleaved logs (Brüchert et al. 2013a, b). X-ray-based CT can therefore be useful to grade product quality (Jover et al. 2013) or even to assess adhesive bond quality in wood-based composites (Muszynski et al. 2013a, b). A particular highlight in CT technology is the demonstrated micrometer-scale resolution of synchrotron-based CT. When combined with acoustic emission measurements, it can provide information on strength development during wood loading (Zauner et al. 2013).

Likewise, X-ray diffraction and scattering methods continue to generate knowledge in wood quality for the detection of spiral grain for example (Grahn et al. 2013) but also again at the micrometer scale, where the micromechanical behavior of the cell wall components can be assessed (Yamamoto et al. 2013). Near-infrared spectroscopy (NIRS) in combination with multivariate analysis is a well-established method for screening various wood traits such as chemical composition or mechanical properties (Rakotovololonalimanana et al. 2013, 2015). Lundqvist et al. (2013) emphasized how imaging NIRS can further help map locally, with 30 microns resolution, particularly wood zones such as high lignin content wood as found in compression wood or heart wood. The characterization of the physico-mechanical properties of especially small wood samples through elastic constants at the millimeter scale is made possible through resonant ultrasound spectroscopy (Longo et al. 2013).

A- and T-Lidar developments are now well progressing for practical forestry (Piboule et al. 2013), including species recognition based on bark aspect (Othmani et al. 2013), resource assessment (Arraiolos et al. 2013; Pont et al. 2013), or research (e.g., biomechanics, Constant et al. 2013).

Methods for data acquisition, data processing, as well as collaborative projects were addressed during the conference. The significant contribution of computing algorithms on data acquisition was clearly demonstrated in taper, sweep, ovality, and mid-diameter assessment of logs scanned by optoelectronic measurement systems (Sauter and Staudenmaier 2013). Developing collaborative projects in this field of research was the main concern of platforms such as COMPUTREE for T-Lidar applications in dendrometry, CAPSIS and AMAP studio in growth and wood quality modelling (de Coligny and Griffon 2013). These platforms encourage the exchange of computational algorithms, models, and user-friendly interfaces. It is essential to outline the contribution of invaluable networks of experimental designs (Osborne et al. 2013; Maguire et al. 2013). These networks are rarely accompanied by the development of chain of models except in a few cases (e.g., ORGANON, see Osborne et al. 2013) and the design of databases allowing the comparisons of wood properties among different species (Lundqvist and Grahn 2013).

\section{Modelling wood properties}

Modelling is spreading toward many topics although for certain wood properties, e.g., defects due to oak epicormics, linking silviculture, and wood quality was considered premature due the complex determinisms (Morisset et al. 2013). Progress has been made in xylogenesis based on chemical signals (sugar, hormones...) diffusing between xylem and phloem along a xylem cell file (Hartmann et al. 2013). Modelling simple processes such as wood swelling appears very promising toward a better understanding of wood cell wall, 
its micromechanical performance, and its response to various treatments (Yamamoto et al. 2013). Moreover, using a fully coupled poro-mechanical approach and multi-scale modelling, Derome et al. (2013) shed light on the mechanisms at play for the shape memory capacity of the wood cell during swelling and shrinking. Mathematical models of weight loss and temperature profiles allow following the kinetics of wood torrefaction (Pétrissans et al. 2013). Likewise, methods probing the molecular motions and dynamics of wood polymers as for example polarization FTIR and dynamic mechanical analysis remain most useful to shed light on the stress/strain behavior across length scales (Salmén 2013, 2015; Auty et al. 2013). With coarse-grained molecular dynamics, relationships between intermolecular interactions among wood structural polymers and the S2 secondary wall can be drawn (Aigner et al. 2013).

The use of appropriate statistical methods have been reasserted for the detection of the limit between juvenile and mature wood (segmented regression, Stewart and Wang 2013), for the prediction of wood density at several heights on Pinus contorta trees (Peng and Stewart 2013), or for the prediction of lumber product assortment from tree size variables within the original notion of "statistical sawmill" (zeroinflated Poisson models, Auty et al. 2013). Finally, the use of mixed models allowed Fischer et al. (2013) to take thoroughly account of the random site and tree effects in the prediction of bending properties modulus of elasticity (MOE) and modulus of rupture (MOR) on Norwegian Norway spruce. Likewise, Filipescu et al. (2013), aiming at refining the empirical models of Douglas fir ring specific density, took advantage of the hierarchical mixed models to quantify the effects of the regional variability due to temperature and precipitations and the thinning regime.

Chains of models are indisputable means to simulate multiusage assortments of the forest resource such as biomass energy (Bilot et al. 2013) or solid wood quality and economic return by taking account of silvicultural regimes and diversity (Moore et al. 2013; Osborne et al. 2013; McLean et al. 2013) and not omitting errors (Schneider et al. 2013).

\section{Traditional assessment of wood properties}

The conference also provided many opportunities, especially during the poster sessions, for discussing "traditional" wood quality. Linking silviculture and wood quality was particularly illustrated for Douglas fir, in either a US (Maguire et al. 2013), Canadian (Filipescu 2013), or European context (Pollet et al. 2013; Henin et al. 2013) and by Baral et al. (2013) on maple. The concern of taking advantage of thick Sugi trees was addressed by Matsumura et al. (2013). The relationship between wood properties and industrial products was particularly depicted with LVL of fast-growing species, either temperate poplar (Rahayu et al. 2013) or Indonesian sengon and jabon
(Anthocephalus cadamba) (Darmawan et al. 2013). Kinetics of wood properties was reported for different processes, along with fungi-induced degradation of transient wooden structures for mountain soil protection (Barré and Bourrier 2013) and during thermal or hygro-thermal treatments (Matsuo et al. 2013). Only one presentation and one poster reported the genetic effect, either on Picea sitchensis (McDonald et al. 2013) or on poplar (Rahayu et al. 2013, 2015). It must be mentioned that reports on wood composites were missing except on the poster of Muszynski et al. (2013a, b), which addressed their micromechanics. Likewise, studies on recomposed wood material (e.g., hardwood glued laminated wooden beams) was only represented by the Ammann et al.'s poster (2013). Their fracture mechanics approach and numerical detection allow assess the effect of size of the wooden pieces and seasonal climate.

\section{Resulting improvement of wood knowledge}

Finally, thanks to various methods of observation and modelling, our knowledge of the wood material made some significant progress. It must be mentioned that the study of around 30 species was reported in the conference, notably the "fastest growing tree on the world" or Indonesian sengon (Paraserianthes falcataria) and the "biological models" Picea abies, Douglas fir and Poplar. We knew more on the wood molecular composition and its influence on the wood properties (Salmén 2013, 2015); on the determinism of swelling (Derome et al. 2013); on the detection of paradoxical equatorial species it means combining rapid growth and "good" wood properties (Bossu 2013); on the impact of bark injury on wood properties (Metzler et al. 2013; Hecht et al. 2015); on the surprising impact of Tectona grandis flowering on ring width, basic density, and MOE (Tondjo et al. 2013 2015); on the weak influence of thinning regime, while a significant negative influence of fertilization and height along the trunk on the basic density on Douglas fir (Maguire et al. 2013); and on the more classical correlations between wood properties (e.g., basic density and strength; Gjerdrum and Eikenes 2013).

At the nanoscopic scale, it emerged that hemicellulose and to a lesser extent lignin exhibits some degree of orientation alongside cellulose microfibrils (Salmén 2013, 2015). When linking this molecular orientation to the mechanical properties, lignin appears to contribute little to stress transfer but might play a key role as a spacer affecting and limiting cellulose aggregation (Salmén 2013, 2015). Likewise, the viscoelastic response of wood upon hotpressing directly correlates to the molecular scale organization of wood and in particular to chain size of the cellulose macromolecules and the resulting microstructure of cellulose (crystallinity index) (Laborie et al. 2013; Reiniati et al. 2015). These findings emphasized how relationships between structure and property develop across all length scales and across wood hierarchical organization. 
Such understanding across scales is essential to advance the engineering and selection of trees and wood traits toward a targeted end use as well highlighted when limiting energy consumption for wood softening in organosolv pulping (Abushammala et al. 2013). Additionally, the understanding of tree and wood biomechanics also entails larger questions of tree ecology and physiology (Fournier and Alméras 2013). In this line, the influence on tree growth and biomechanics of chronic winds is currently under study (Bonnesoeur et al. 2013). The properties of the wood are thus more and more understood even the wood surface appearance (Breinig et al. 2013) notably thanks to innovative optical method designed to detect checks on veneer surface (Burnard et al. 2013). Conversely the objective quantification of the properties on which the perception of the wood quality is based is less advanced (Manuel et al. 2013, 2015).

\section{Perspectives}

The multi-scale presentation of wood studies with both methodological and modelling concerns, tested in this conference, has been indisputably extremely rewarding. We feel that this presentation was a relevant opportunity to share and recover ideas and resume collaboration on data acquisition and modelling approaches. However, to have gathered scientific communities that are involved in too distant topics may have prevented in-depth exchanges within each specific topic.

One way to maintain a multi-scale approach should be to maintain a focus on the transversal originality and historical core of the IUFRO Unit 5.01.04 which is Modelling. This topic remains original compared to the other IUFRO units dedicated to wood. The unit 5.01.04 should address not specifically quality modelling but rather Modelling of multi-scale properties. The measurement methods will be necessarily mentioned especially those allowing study properties that are not yet routinely tackled.

We are extremely confident about the next conference which will be organized in Quebec during June 2016 under the leadership of Alex Achim, Professor at Laval University. It will allow to deepen the recovered friendliness of the recently extended IUFRO group 5.01.04 and preserve the necessary balance between observation scales.

\section{References}

Abushammala H, Pontes F, Gomez JG, Osorio-Madrazo A, Thire R, Pereira FV, Krossing I, Laborie MP (2013) Swelling and viscoelastic studies of Norway spruce: combining tools to study ionic liquidwood molecular interactions towards organosolv pulping. https:// colloque6.inra.fr/memowood/MeMoWood-presentations. Accessed 13 May 2015
Aigner N, Colombo J, Burgert J, Del Gado E (2013) Building a mesoscale model of the S2 secondary wood cell wall. https://colloque6. inra.fr/memowood/MeMoWood-presentations. Accessed 13 May 2015

Ammann S, Hassani M, Wittel F, Herrmann H, Niemz P (2013) Adhesive bonding of structural hardwood elements. Poster abstract. https:// colloque6.inra.fr/memowood/MeMoWood-presentations. Accessed 13 May 2015

Arciniegas A, Brancheriau L, Lasaygues P (2013) Improving acoustic tomography resolution by optimizing the wave travel time detection. https://colloque6.inra.fr/memowood/MeMoWood-presentations. Accessed 13 May 2015

Arciniegas A, Brancheriau L, Lasaygue P (2015) Tomography in standing trees: revisiting the determination of acoustic wave velocity. Ann For Sci (this issue). doi:10.1007/s13595-014-0416-y

Arraiolos A, Moreau J, Vuillermoz M (2013) LiDAR technologies combined to wood properties models: a solution to improve wood allocation? Results of a first study case in Aquitaine for Pinus pinaster. https://colloque6.inra.fr/memowood/MeMoWood-presentations. Accessed 13 May 2015

Auty D, Achim A, Bédard P, Pothier D (2013) Modelling lumber product assortment and value using zero-inflated Poisson (ZIP) regression. https://colloque6.inra.fr/memowood/MeMoWood-presentations. Accessed 13 May 2015

Baral SK, Schneider R, Pothier D, Berninger F (2013) Effects of inter-tree competition on tree crown characteristics and clear wood production of sugar maple. https://colloque6.inra.fr/memowood/MeMoWoodpresentations. Accessed 13 May 2015

Barré J-B, Bourrier F (2013) Characterization of the fungal degradation of wood. Poster https://colloque6.inra.fr/memowood/MeMoWoodpresentations. Accessed 13 May 2015

Bilot N, Wernsdorfer H, Rogaume Y, Fournier M (2013) ForEnerChips. A simulator to assess energy performance and mineral exportations due to energy uses of forest biomass. https://colloque6.inra.fr/ memowood/MeMoWood-presentations. Accessed 13 May 2015

Bonnesoeur V, Constant T, Moulia B, Fournier M (2013) Modelling the acclimation to wind of the aerial part of beech. https://colloque6. inra.fr/memowood/MeMoWood-presentations. Accessed 13 May 2015

Bossu J (2013) Looking for "paradoxical" species for a sustainable forest management in French Guiana. https://colloque6.inra.fr/ memowood/MeMoWood-presentations. Accessed 13 May 2015

Breinig L, Leonhart R, Manuel M, Broman O, Brüchert F, Becker G, Sauter UH (2013) Classification of wooden surfaces according to aesthetical appearance by aid of optical scanner data. https:// colloque6.inra.fr/memowood/MeMoWood-presentations. Accessed 13 May 2015

Brüchert F, Müller C, Frese M, Böhringer A, Sauter UH, Fillbrandt T (2013a) Simulation of compression capacity of naturally grown small-dimensioned hardwood based on CT-extraction of the geometrical shape under bark. Abstract https://colloque6.inra.fr/ memowood/MeMoWood-presentations. Accessed 13 May 2015

Brüchert F, Uhlich U, Becker G, Sauter UH, Seho M (2013b) Black pine (Pinus nigra Arnold) - X-ray based computed tomography and laser interferometry on roundwood as prediction tools for strength grading of structural timber. Abstract. https://colloque6.inra.fr/ memowood/MeMoWood-presentations. Accessed 13 May 2015

Burnard M, Muszynski L, Leavengood S, Ganio L (2013) Rapid assessment of check development in veneer overlays. Poster. https:// colloque6.inra.fr/memowood/MeMoWood-presentations. Accessed 13 May 2015

Constant T, Dassot M, Ningre F, Morisset JB, Chaumet M, Barbacci A, Fournier M (2013) Feedbacks about the use of terrestrial LiDAR within the field of tree biomechanics. https://colloque6.inra.fr/ memowood/MeMoWood-presentations. Accessed 13 May 2015 
Coops N (2013) Introduction to LiDAR technology and its potential for estimation of wood attributes. https://colloque6.inra.fr/memowood/ MeMoWood-presentations. Accessed 13 May 2015

Darmawan W, Istie, Nandika D, Fournier M, Marchal R (2013) Development of high performance laminated veneer lumber (LVL) made of fast growing wood species. https://colloque6.inra.fr/ memowood/MeMoWood-presentations. Accessed 13 May 2015

De Coligny F, Griffon S (2013) Capsis/AMAPstudio. The benefit of integrative software platforms for models mutualisation and chaining. https://colloque6.inra.fr/memowood/MeMoWoodpresentations. Accessed 13 May 2015

Derome D, Rafsanjani A, Patera A, Kulasinski K, Guyer R, Carmeliet J (2013) What is swelling of wood? https://colloque6.inra.fr/ memowood/MeMoWood-presentations. Accessed 13 May 2015

Duchateau E, Genet A, Mothe F, Longuetaud F, Auty D, Ung CH, Achim A (2013) Using CT-scanning data to model knot morphology, development and orientation. https://colloque6.inra.fr/memowood/ MeMoWood-presentations. Accessed 13 May 2015

Filipescu C (2013) Comparative assessment of destructive and nondestructive measurement methods: a case study in Douglas-fir following late rotation fertilization. Poster https://colloque6.inra.fr/ memowood/MeMoWood-presentations. Accessed 13 May 2015

Filipescu C, Lowell E, Koppenaal R (2013) Regional and climatic variability in ring attributes of intensively managed Douglas-fir. A hierarchical mixed-effects modeling approach. https://colloque6.inra.fr/ memowood/MeMoWood-presentations. Accessed 13 May 2015

Fischer C, VestØl GI, HØibØ OA (2013) Modeling the effect of standand tree characteristics on the accuracy of strength grading of spruce timber. https://colloque6.inra.fr/memowood/MeMoWoodpresentations. Accessed 13 May 2015

Fournier M, Alméras T (2013) Relationships between wood functions in the living tree and wood industrial qualities: what can we expect from tree mechanical research? https://colloque6.inra.fr/ memowood/MeMoWood-presentations. Accessed 13 May 2015

Gazo R, Abdul-Massih M, Vanek J, Haviarova E, Benes B (2013) An efficient pith detection for computer tomography scanned logs using CUDA. https://colloque6.inra.fr/memowood/MeMoWoodpresentations. Accessed 13 May 2015

Gjerdrum P, Eikenes B (2013) Co-variation and stochastic elements between various strength properties for Norway spruce. https:// colloque6.inra.fr/memowood/MeMoWood-presentations. Accessed 13 May 2015

Grahn T, Lundqvist S-O, Olsson L (2013) Measurement of radial variations in spiral grain with X-ray diffraction on SilviScan. https:// colloque6.inra.fr/memowood/MeMoWood-presentations. Accessed 13 May 2015

Happe R, Hapla F (2013) Detection of ring shake in sweet chestnut (Castanea sativa Mill) using different tomography systems. https://colloque6.inra.fr/memowood/MeMoWood-presentations. Accessed 13 May 2015

Hartmann FP, Rathgeber C, Moulia B, Fournier M (2013) Biophysical modeling of wood formation in conifers. https://colloque6.inra.fr/ memowood/MeMoWood-presentations. Accessed 13 May 2015

Hecht U, Kohnle U, Nill M, Grüner J, Metzler B (2015) Bark wounds caused by felling are more susceptible to discoloration and decay than wounds caused by extraction in European beech. Ann For Sci (this issue). doi:10.1007/s13595-014-0432-y/

Henin J-M, Hebert J, Jourez B (2013) Impact of growth rate on the distribution of visually strength-graded West-European Douglas-fir boards. Poster https://colloque6.inra.fr/memowood/MeMoWoodpresentations. Accessed 13 May 2015

Jover J, Almecija B, Bombardier V, Thomas A, Charpentier P (2013) Product quality classification using $\mathrm{X}$ ray tomography. https:// colloque6.inra.fr/memowood/MeMoWood-presentations. Accessed 13 May 2015
Laborie M-P, Reiniati I, Osman N, Mc.Donald A (2013) Modeling the molecular-scale behavior of wood polymers during heat compression of hybrid poplar: impact on bulk wood viscoelastic and physical responses. https://colloque6.inra.fr/memowood/MeMoWoodpresentations. Accessed 13 May 2015

Leban J-M, Peltola H, Leinonen S, Todoroki C, D'Amours S, Gardiner B, Goudie J, Lowell E, Seifert T, Verkasalo E, Wilhelmsson L, Nuutinen T, 2009 Preface. In Proceedings of the 6th IUFRO Workshop on Connection Between Forest Resources and Wood Quality: Modeling Approaches and Simulation Software, Joensuu, Finland, 8-14 June 2008. Silva Fennica 2009 Vol. 43(3): pp $327-$ 328

Longo R, Arnould O, Laux D, Delaunay T, Pagano S, Le Clezio E (2013) Wood elastic characterization from a single sample by resonant ultrasound spectroscopy. Abstract. https://colloque6.inra.fr/ memowood/MeMoWood-presentations. Accessed 13 May 2015

Longuetaud F, Roussel JR, Colin F, Mothe F, Krähenbühl A, Kerautret B, Debled-Renessson I (2013) Knot detection in CT images of logs. https://colloque6.inra.fr/memowood/MeMoWood-presentations. Accessed 13 May 2015

Lundqvist S-O, Grahn T, Wallbäcks L (2013) Imaging NIR spectroscopy for investigation of wood and applications on wood materials. https://colloque6.inra.fr/memowood/MeMoWood-presentations. Accessed 13 May 2015

Lunqvist S-O, Grahn T (2013) Framework for multi-species comparison and relationships between wood, fibre and product properties. https://colloque6.inra.fr/memowood/MeMoWood-presentations. Accessed 13 May 2015

Maguire D, Mainwaring D, Bluhm A, Harrison R, Turnblom E (2013) Response of Douglas-fir wood density to intensive thinning and fertilization. https://colloque6.inra.fr/memowood/MeMoWoodpresentations. Accessed 13 May 2015

Manuel A, Breinig L, Leonhart R, Broman O, Becker G (2013) What makes wood so attractive? https://colloque6.inra.fr/memowood/ MeMoWood-presentations. Accessed 13 May 2015

Manuel A, Leonhart R, Broman O, Becker G (2015) Consumers' perceptions and preference profiles for wood surfaces tested with pairwise comparison in Germany. Ann For Sci (this issue). doi:10.1007/ s13595-014-0452-7

Matsumura Y, Murata K, Ikami Y, Matsumura J (2013) Relationships between wood properties of large-diameter Sugi (Cryptomeria japonica) $\operatorname{logs}$ and lumber quality. Poster. https://colloque6.inra.fr/ memowood/MeMoWood-presentations. Accessed 13 May 2015

Matsuo M, Karami E, Pardet S, Froidevaux J, Yoshida M, Yamamoto H, Gril J (2013) Modeling of the changes in wood properties during thermal and hygro-thermal treatment. Poster https://colloque6.inra. $\mathrm{fr} / \mathrm{memowood} /$ MeMoWood-presentations. Accessed 13 May 2015

McDonald E, Lee S, Connolly T, Cameron A (2013) Improving the mechanical properties and performance of Sitka spruce (Picea sitchensis) timber through selection and breeding. Poster https:// colloque6.inra.fr/memowood/MeMoWood-presentations. Accessed 13 May 2015

McLean JP, Gardiner B, Moore J, Adams S (2013) Modelling variability in raw material properties of the UK forest resource...through building chains of models! https://colloque6.inra.fr/memowood/ MeMoWood-presentations. Accessed 13 May 2015

Metzler B, Hecht U, Kohnle U (2013) Specific impact of bark wounds on wood properties in Norway spruce, silver fir, and beech. https:// colloque6.inra.fr/memowood/MeMoWood-presentations. Accessed 13 May 2015

Moore J, Harrington J, Cown D, Pont D, West G (2013) Linking forest management, wood quality and end-product performance in radiata pine. https://colloque6.inra.fr/memowood/MeMoWoodpresentations. Accessed 13 May 2015

Morisset JB, Colin F, Mothe F (2013) How to simulate wood quality depreciation by epicormics? Ontogeny, tentative modelling and 
perspectives for oak. https://colloque6.inra.fr/memowood/ MeMoWood-presentations. Accessed 13 May 2015

Muszynski L, Kamke FA, Nairn JA, Schwarzkopf M, Paris J (2013a) Towards an integrated methodology for multi-scale/multi-modal investigation of micro-mechanical wood adhesive interaction. https:// colloque6.inra.fr/memowood/MeMoWood-presentations. Accessed 13 May 2015

Muszynski L, Schwarzkopf M, Nairn JA (2013b) An integrated method for measurement and modeling of the micromechanics of the internal bond in wood plastic composites (WPCs). Poster https:// colloque6.inra.fr/memowood/MeMoWood-presentations. Accessed 13 May 2015

Osborne N, Maguire D, Hann D (2013) Modeling the effects of silvicultural regime on Douglas-fir crown morphology and related wood quality attributes. https://colloque6.inra.fr/memowood/ MeMoWood-presentations. Accessed 13 May 2015

Othmani A, Piboule A, Lew Yan Voon LFC (2013) Tree species recognition from T-LiDAR data for forest inventory. Poster https:// colloque6.inra.fr/memowood/MeMoWood-presentations. Accessed 13 May 2015

Peng M, Stewart JD (2013) Modelling wood density for industrial application. Poster abstract. https://colloque6.inra.fr/memowood/ MeMoWood-presentations. Accessed 13 May 2015

Pétrissans A, Hamada J, Chaouch M, Pétrissans M, Gérardin P (2013) Modeling and numerical simulation of wood torrefaction. https:// colloque6.inra.fr/memowood/MeMoWood-presentations. Accessed 13 May 2015

Piboule A, Krebs M, Esclatine L, Hervé J-C (2013) Computree: a collaborative platform for use of terrestrial LiDAR in dendrometry. https:// colloque6.inra.fr/memowood/MeMoWood-presentations. Accessed 13 May 2015

Pollet C, Henin J-M, Hébert J, Jourez B (2013) Impact of growth rate on the mechanical properties of Douglas-fir grown in Wallonia (Southern Belgium). Poster https://colloque6.inra.fr/memowood/ MeMoWood-presentations. Accessed 13 May 2015

Pont D, Morgenroth J, Watt MS (2013) Tree-based analysis of ALS to estimate tree size and quality. https://colloque6.inra.fr/memowood/ MeMoWood-presentations. Accessed 13 May 2015

Rahayu I, Denaud L, Marchal R, Darmawan W (2013) Correlation between radial variation and mechanical properties of laminated veneer lumber made from 14 poplar cultivars. https://colloque6.inra.fr/ memowood/MeMoWood-presentations. Accessed 13 May 2015

Rahayu I, Denaud L, Marchal R, Darmawan W (2015) Ten new poplar cultivars provide laminated veneer lumber for structural application. Ann For Sci (this issue). doi:10.1007/s13595-014-0422-0

Rakotovololonalimanana H, Chaix G, Brancheriau L, Ramamonjisoa L, Ramananantoandro T, Thevenon M-F (2013) Prediction of the modulus of elasticity (MOE) by near infra-red spectroscopy (NIRS) and direct measurement by ultrasonic device (Uscan) from cores of Liquidambar (Liquidambar styraciflua (L.)) from Madagascar. https://colloque6.inra.fr/memowood/MeMoWood-presentations. Accessed 13 May 2015

Rakotovololonalimanana H, Chaix G, Brancheriau L, Ramamonjisoa L, Ramananantoandro T, Thevenon M-F (2015) A novel method to correct for wood MOE Ultrasonics and NIRS measurements on increment cores in Liquidambar styraciflua L. Ann For Sci (this issue). doi:10.1007/s13595-015-0469-6

Reiniati I, Osman NB, Mc Donald AG, Laborie MP (2015) Linear viscoelasticity of hot-pressed hybrid poplar relates to densification and to the in situ molecular parameters of cellulose. Ann For Sci (this issue). doi:10.1007/s13595-014-0421-1

Salmén L (2013) Wood morphology and properties from molecular perspectives. https://colloque6.inra.fr/memowood/MeMoWoodpresentations. Accessed 13 May 2015

Salmén L (2015) Wood morphology and properties from molecular perspectives. Ann For Sci (this issue). doi:10.1007/s13595-014-0403-3

Sauter UH, Staudenmaier J (2013) Opto-electronic round wood measurement and modeling. https://colloque6.inra.fr/memowood/ MeMoWood-presentations. Accessed 13 May 2015

Schneider R, Fortin M, Saucier J-P (2013) Predicting stem diameter and its error: the first step in evaluating product recovery on large forested areas. https://colloque6.inra.fr/memowood/MeMoWoodpresentations. Accessed 13 May 2015

Skog KT, Wegner TE, Ince P, Michler CH (2013) Desirable properties of wood in the $21^{\text {st }}$ century. https://colloque6.inra.fr/memowood/ MeMoWood-presentations. Accessed 13 May 2015

Skog KE, Wegner TE, Bilek EM, Michler CH (2015) Desirable properties of wood for sustainable development in the $21^{\text {st }}$ century. Ann For Sci (this issue). doi:10.1007/s13595-014-0406-0

Stewart JD, Wang M (2013) Segmented regression models predict the transition from juvenile to mature wood, but is it real? https:// colloque6.inra.fr/memowood/MeMoWood-presentations. Accessed 13 May 2015

Thibaut B (2013) From tree to end-product: construction, deconstruction and reconstruction. https://colloque6.inra.fr/memowood/ MeMoWood-presentations. Accessed 13 May 2015

Tondjo K, Brancheriau L, Sabatier S-A, Kokutse AD, Akossou A, Fourcaud T, Kokou K (2013) Relationships between tree architecture and wood physical properties of Tectona grandis (Teak). https:// colloque6.inra.fr/memowood/MeMoWood-presentations. Accessed 13 May 2015

Tondjo K, Brancheriau L, Sabatier S-A, Kokutse AD, Akossou A, Kokou K, Fourcaud T (2015) Is the variability of key wood properties linked with the variability of key architectural traits? Case of planted Teak in Togo regarding thinning and provenance. Ann For Sci (this issue). doi:10.1007/s13595-014-0425-x

Weiskittel A (2013) Forest growth and wood quality modeling: past, present and future. https://colloque6.inra.fr/memowood/ MeMoWood-presentations. Accessed 13 May 2015

Yamamoto H, Toba K, Yoshida M, Matsuo M, Abe K, Nakai T, Ruelle J (2013) Application of X-ray diffraction technique to analyzing micromechanical properties of wood cell wall. https://colloque6. inra.fr/memowood/MeMoWood-presentations. Accessed 13 May 2015

Zauner M, Ritschel F, Brunner AJ, Niemz P (2013) Synchrotron microtomography and acoustic emission monitoring during in-situ loading of miniature spruce wood samples. https://colloque6.inra.fr/ memowood/MeMoWood-presentations. Accessed 13 May 2015 